It appears therefore that, just as in the case of the apple and the banana, an active substance (perhaps ethylene) is produced by ripe Kelsey plums, which is capable of accelerating the ripening process in unripe Kelsey plums. There is, however, reason to believe that relative humidity also plays a part, but critical experiments on these lines have still to be made.

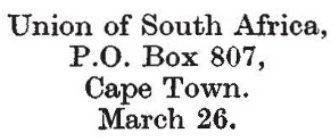

\section{The Polysaccharide produced from Sucrose by Leuconostoc dextranicum}

THE chemical investigation of the 'dextran' formed when Leuconostoc dextranicum is grown on media con. taining sucrose ${ }^{1}$ has given information concerning the structure of the polysaccharide and has revealed facts which have a bearing on the general biological question of enzymatic synthesis.

The purest dextran isolated is a water-soluble and non-reducing white powder with a high positive rotation $\left([\alpha]_{D}^{200}+180^{\circ}\right.$ in water $)$; it appears to be constituted entirely of glucose units. After hydrolysis by boiling normal sulphuric acid, glucose in crystalline form was separated from the hydrolysate in 92 per cent yield.

No difficulty was experienced in methylating the dextran by the usual procedure with methyl sulphate and sodium hydroxide, and fractional precipitation of the methylated product showed it to be essentially homogeneous $\left([\alpha]_{D} 210-214^{\circ}\right.$ in chloroform; OMe, 44.5 per cent). The methylated dextran is more stable to hydrolytic agents than is methylated starch. Complete hydrolysis of the methylated dextran was achieved by heating with the reagent usually employed in this laboratory for the hydrolysis of methylated cellulose, namely, 50 per cent aqueous acetic acid containing 4 per cent concentrated hydrochloric acid. Separation of the hydrolytic products was effected in the usual way by treatment with methyl alcoholic hydrogen chloride and fractional distillation in a vacuum.

The principal product of hydrolysis was $2: 3: 4$ trimethyl glucopyranose isolated as the crystalline $\beta$-methyl glucoside (m.p. 94-95 $;[\alpha]_{D}-21^{\circ}$ in water). The trimethyl sugar $\left([\alpha]_{D}+68^{\circ}\right.$ equilibrium value) gave a crystalline anilide (m.p. $145-6^{\circ}$ ), was oxidized by bromine water to a $\delta$-lactone $\left([\alpha]_{D}+80^{\circ} \rightarrow+32^{\circ}\right.$ in $21 \mathrm{hr}$.) and by nitric acid to $2: 3: 4$ trimethyl saccharolactone methyl ester (m.p. 106-107 ${ }^{\circ}$ alone or in admixture with an authentic specimen).

The fractions obtained in the vacuum distillation of the glucosides were contaminated with methyl lævulinate (characterized as the phenylhydrazone, m.p. $106^{\circ}$ ), and it was found advisable to remove this constituent by treatment with barium hydroxide and then to refractionate the glucosides. There were indications, chiefly from the refractive index, of the presence of a small amount of tetramethyl methyl glucoside in the first fraction which, after hydrolysis with aqueous acid, had OMe 46 per cent (a trimethyl sugar requires OMe 41.9 per cent). This was confirmed when the methylated sugars from the hydrolysed first fraction were heated with aniline. The anilide which separated was tetramethyl glucose anilide (found OMe $40 \cdot 3$ per cent; $\mathrm{C}_{16} \mathrm{H}_{25} \mathrm{O}_{5} \mathrm{~N}$ requires $\mathrm{OMe} 40$ per cent). After recrystallization from absolute alcohol, the anilide had m.p. 135-6 ${ }^{\circ}$ and there was no depression of melting point in admixture with an anilide prepared by the same method from crystalline tetramethyl glucopyranose.

Full details will be published later, but it would appear from these results that the dextran resembles starch and cellulose in that it is constituted solely of glucose residues united to form a chain molecule. The fact that $2: 3: 4$ trimethyl glucose is the main product of hydrolysis of methylated dextran establishes the nature of the link between the glucose units as being 1:6-glucosidic (the gentiobiose linkage) and the isolation of tetramethyl glucose suggests a terminated chain. The proportion of tetramethyl glucose is estimated to be approximately 0.23 per cent of the weight of methylated dextran, which corresponds to a chain length of 550 glucose units. No finality is attached to this latter figure, especially as an osmotic pressure determination gave 200 units, and the possibility of effecting a quantitative separation of tetramethyl glucose as the anilide is being explored.

\section{S. Peat.}

M. Stacey.

E. SCHLÜCHTERER.

A. E. Hills Laboratories,

University of Birmingham,

Edgbaston.

April 8.

${ }^{1}$ Carruthers, A., and Cooper, E. A., Biochem. J., 30, 1001 (1936).

\section{The Oxidation-Reduction Potential in Lignifying Cells}

DuRING the lignification process of the cell walls the carbon content increases considerably. A strong reduction must take place in the living cells which begin to lignify. We have tried to determine the reduction potential of the tissues by means of the colorimetric method applied thus far only to isolated cells (unicellular organisms, and in yeast- and bacteria-suspensions). The results are still of a qualitative character, but they seem significant.

Tissues scraped from the hypocotyledons of the stems of sunflowers by means of a piece of broken glass were used : (1) cortical parenchyma ; (2) cambium tissue near the xylem ; (3) cambium tissue near the phloem ; (4) older wood tissue; and (5) medullary parenchyma. These tissues, after carefully washing off the adherent cell juice, were brought into Thunberg-tubes filled with 8 c.c. of very dilute $(0 \cdot 001-0 \cdot 005$ per cent) solutions of oxidation-reduction indicators (six dyes were used, ranging from $r \mathrm{H} 18$ to $r \mathrm{H} 8$ ) and 2 c.c. of the Sörensen phosphate buffers $(p H=7)$. After evacuation, the glass tubes were placed in an incubator at $30^{\circ} \mathrm{C}$. Tubes filled only with solutions of the dyes for comparison of the colour, and tubes filled with liquid and killed tissues, which do not reduce, served as controls.

The cambium tissue near the xylem reduced most quickly and intensely. In the cortex the reduction was less marked. The medullary parenchyma had a much weaker action, while the activity of the older wood tissue (of course dead for the greater part) was very scanty.

A corroborative result was obtained with transverse sections of the stem. The results were very satis. factory in most cases, notwithstanding the unfavourable period (autumn). They were, however, variable according to the vitality of the plants used. The 